\title{
Energy management of industrial enterprise
}

\author{
E.A. Lyaskovskaya ${ }^{1, *}$, and M.R. Kurbangaliev ${ }^{1}$ \\ ${ }^{1}$ South Ural State University, Chelyabinsk, Russia
}

\begin{abstract}
In the intensifying condition of economic situation and increasing competitiveness in domestic and foreign markets, the most important way to develop competitive ability of an industrial company is to reduce energy costs in the production process. Insufficient level of the efficiency of energy resources usage affects an industrial company's performance indicators and its investment attractiveness. A promising way of solving this matter is to develop and implement a strategy of rational energy consumption, which is aimed at the realization of company's potential to optimize the consumption of electric energy by using internal and external resources in order to minimize energy costs. The strategy of rational energy consumption defines how an industrial company acquires electric energy and uses it to sustain the production. While developing and implementing the strategy, one should use a systemic and complex way and consider the following: peculiarities of electric energy and power as products; the structure of electric energy market and the possibilities of its consumers; peculiarities of price-formation on electric energy market; technical and technological, organizational and administrative, social and economic parameters of a company, characteristic features of its resource potential and production processes; the results of company's energy efficiency audit and energy problems; company's reserves that can increase its energy efficiency. An integral strategy of energy consumption includes a strategy for energy preservation and efficiency and a strategy for energy costs management. Both strategies are interrelated and serve for one purpose, which is minimizing the energy costs. This division helps simplify the analysis, search for alternatives and realization of energy management on operative, tactical and strategic levels, considering the regional and industryspecific peculiarities of an industrial company, its financial performance and efficiency.
\end{abstract}

\section{Introduction}

Lately there has been a reform in Russian electric-power industry, which resulted in a completely new industry structure, new procedural and institutional form of enterprises in the industry, new open market of electric energy and power. Due to this the prices on electric power boosted, growth rates became threatening high, overcoming ones in the developed countries (USA and EU). The increasing prices on energy affect Russian industrial businesses as major energy consumers, which in the first place shows up in the energy costs and, as follows, in the production costs. The industry competitiveness increased after Russia has become a member of WTO. The expansion of Chinese businesses, economic measures against our country, the negative air in the economic situation that still remains since the crisis of 2008 - all this increase competitiveness even more. An important direction in this view is lowering energy costs, namely the costs of electric energy and power consumption. For an industrial company these costs can be lowered by effective rational management of energy consumption, based on energy saving, increased energy efficiency and management of energy costs.

\footnotetext{
Corresponding author: elen_lea@mail.ru
}

Many Russian scientists have studied the field, such as I.A. Baev, B.I. Kudrin, L.D. Ghitelman, A.V. Sedov, E.E. Tikhonov, A.I. Tatarkin, V.G. Mokhov, V.V. Karpov, V.I. Gordeev, V.P. Stepanov, J.A. Fokin and others. Despite impressive results achieved by them, there is still no sufficient way to overcome the problems of strategic energy management on Russian market.

\section{Problems in reforming electric-power industry in Russian Federation}

In 2001-2008 years Russian electric-power industry has been reformed. It was adapted to modern conditions of economic management. During the reformation process dramatic changes took place in the industry (the industry structure was completely changed, a new normative framework and regulation system were formed etc.). These changes affected not only companies in the sphere of energy supply, but also the consumers of energy [1-9]. Present situation in the electric-energy and power industry can be described like this

- Poor technical performance in russian power suppliers.

- Absence of motivation to increase efficiency, energy saving, rational planning of producing and consuming electric energy, frequent cases of non-payments from consumers of energy. 
- Absence of informational and financial transparency among power suppliers.

- Low profitability of energy sphere.

- Lack of investments.

- Cases of "rolling black-outs", frequent "black-outs" in particular regions.

- Decreasing reliability of power suppliers in many regions of Russia.

- New independent players have no possibility to enter the market.

- Absence of conditions for healthy competitiveness, uncompetitive price-formation.

During the reformation electric energy prices were constantly rising [10], power grid system contributed to this significantly. The origins of the increase in network rates are as follows

- Mistakes in the implementation of rab - rate-regulatory system, which is aimed at attracting investments to power grid system.

- Absence of proper supervision over the spending of the assets of investment projects.

- Dishonest regional power grid organizations.

- Unsolved issue of cross-funding and redistribution of electricity payments among several groups of consumers, when electric energy costs for citizens are partially covered by industrial consumers.

Summing this up, we can draw an unsettling conclusion: the reformation cannot be called complete, as nearly none of the planned goals is ultimately reached. In the producing sector there is still no way to effectively stimulate business initiative and competitiveness that can contribute to energy preservation, lowering production costs and increasing production efficiency. In the trading sector, just like in the producing sector, there are still no means of creating healthy competitiveness. The problem is common for the whole industry - the industry does not have any effective state supervising and proper state regulation.

\section{Analysis of market of electric energy and power in the Russian Federation}

Russian market of electric energy and power has sophisticated structure due to specificity of electric energy and power as products, vast territory of the Russian Federation, insufficiently developed power distribution structure and others. Due to certain features, determined by physical properties of electric energy, peculiarities of its production and storing processes, electric energy is a specific product. At first, electric energy cannot be stored in amounts, corresponding to the scales of energy system. Only constant balance between the production and the consumption can provide stable functioning of market in this sphere. At second, from consumer's point of view all producers act as one producer, and from producer's point of view - all consumers act as one consumer [11-14]. At third, planning and estimation of production and consumption of electric energy is needed $\mathrm{n}$ order to organize normal functioning of energy system. The amounts of production are directly linked to the amounts of consumption here, so it is important to evaluate the amount of consumption, which are not constant. At fourth, timely balancing of the whole energy system is obligatory.

Impossibility to store electric energy and the absence of substitute products determine the necessity of accumulation of backups of generating capacities, power grids and fuel at power plants [12]. It leads to the fact that consumers pay not only for the amount of electric energy they consume, but also for the possibility of consuming. Price for actual consuming is price for electric energy as the main product on the electric energy market. Price for the possibility of consuming is price for power as a specific product, that provides every consumer with a possibility to use backup generating capacities to satisfy consumer's demand in electric energy [11-14].

Presently there is a sophisticated system of price formation on the Russian market of electric energy and power. This system lets industrial consumers choose their rates and therefore change the final price for consumption of electric energy and power. Only for that industrial consumers should develop their energy management strategies, hold technical and organizational activities managing price levels. Implementation of such activities does not presume direct reduction of consumption of electric energy, which can be achieved only by implementing energy efficiency activities [1114].

\section{Problems in energy consumption efficiency among Russian industrial companies}

It is historically developed that industrial sector in the Russian Federation, inherited from the Soviet Union, was a rather energy demanding economy sector. It was determined by following factors

- Structure of production, developed during a long period of time.

- High moral and physical exhaustion of major production assets of industrial companies.

- Technological undevelopment of industrial sector.

- Severe environmental conditions.

- Cheap energy resources, including electric energy [15$16]$.

In the middle of 1990s energy demands of Russian economy was 2 -3 times higher than the same indicator for developed countries. The main reason was absence of interest from owners of industrial companies in the modernization of production and in rational use of energy resources, including electric energy. The last can be explained by following factors

- Electricity rates, artificially lowered by state.

- Low level of accounting, control and regulation of electric energy consumption [17-19].

In the 2000s government developed a number of measures, aimed at reducing energy demand of industrial sector. Federal law "About energy preservation and increasing energy efficiency" became one of the means of realization of energy preservation and increasing 
energy efficiency [5]. After Russia got membership in WTO the problem of managing energy consumption on industrial companies become more and more vital.

The moving forces for implementation of activities aimed at energy preservation and increasing energy efficiency are

- The increase of prices of electric energy.

- The decrease of costs for electric energy.

- The decrease of production costs.

- The increase of profitability and competitive ability of a company.

Besides, there are also factors that impede the implementation of activities aimed at energy preservation and increasing energy efficiency. The usually are following [17-19,22]

- Absence or lack of financial resources for development, verification, implementation and monitoring of energy preservation activities.

- Absence of motivation among personnel.

- Low level of knowledge in the field of energy preservation and increasing energy efficiency among management.

- Lack of information on the methods of energy preservation and increasing energy efficiency.

- There are usually two major directions of energy preservation and increasing energy efficiency in an industrial company [20-21].

- Extensive energy preservation, based on quantitative decrease of energy consumption.

- Intensive energy preservation that implies qualitative change in the system of power supplying and consumption.

In order to manage energy consumption in an industrial company, energy management systems should be implemented. The notion of energy management is in a way a synonym to energy consumption management and includes structure, resources, processes and procedures necessary for realization of planning, organization, providing the realization, evaluation, analysis and monitoring of energy policy and achieving energy goals of a company I order to increase its competitive ability [17-19].

\section{Strategy of rational energy consumption in an industrial company}

In our view, strategy of rational energy consumption in an industrial company - is a part of company's general strategy, aimed at the realization of company's potential to optimize the consumption of electric energy by using internal and external resources in order to minimize energy costs. The strategy defines how an industrial company acquires electric energy and uses it to sustain the production. According to its major goals, strategy of rational energy consumption in an industrial company can be divided into two parts

- Strategy for energy preservation and efficiency.

- Strategy for energy costs management.

Each of the parts serves for the general purpose of strategy of rational energy consumption but use different ways of achieving it.
This division helps simplify the analysis, search for alternatives and realization of energy management on operative, tactical and strategic levels, considering the regional and industry-specific peculiarities of an industrial company, its financial performance and efficiency.

The sequence of stages of strategic management of energy consumption in an industrial company can be presented like this (Fig. 1).

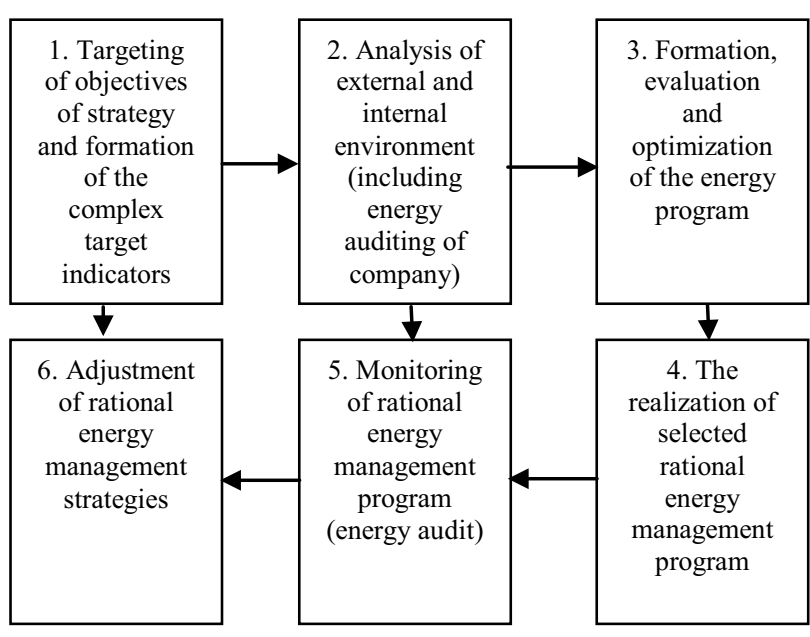

Fig. 1. Stages of development of strategy of rational energy consumption in an industrial company.

Characteristics of strategy of rational energy consumption in an industrial company are presented in table 1 .

Table 1. Characteristics of strategy of rational energy consumption in an industrial company

\begin{tabular}{|c|c|}
\hline $\begin{array}{c}\text { Strategic } \\
\text { components }\end{array}$ & Detalisation of strategic components \\
\hline goal & Minimize energy costs for a company. \\
\hline issues & $\begin{array}{l}\text { Energy preservation, energy efficiency increase } \\
\text { on production. } \\
\text { Lowering the costs of acquired electric energy } \\
\text { and power. }\end{array}$ \\
\hline substrategies & $\begin{array}{c}\text { Substrategy for energy preservation and } \\
\text { efficiency, aimed at reducing the amounts of } \\
\text { electric energy consumption. } \\
\text { Substrategy for energy costs management, aimed } \\
\text { at reducing the costs of acquired electric energy } \\
\text { and power. }\end{array}$ \\
\hline $\begin{array}{l}\text { factors that } \\
\text { affect the } \\
\text { costs of } \\
\text { energy } \\
\text { consumtion } \\
\text { and } \\
\text { possibilities } \\
\text { for energy } \\
\text { preservation } \\
\text { in a } \\
\text { company }\end{array}$ & $\begin{array}{l}\text { Technical factors (quality of materials, } \\
\text { equipment, hardware, availability and quality of } \\
\text { commercial accounting system etc.). } \\
\text { Technological factors (technology, list of } \\
\text { equipment, technological working patterns etc.). } \\
\text { Organizational factors (company's working } \\
\text { patterns and schedules, level of planning, } \\
\text { operative production schedule etc.). } \\
\text { Social factors (level of qualification and loyalty } \\
\text { among employees, personnel motivation, } \\
\text { necessity to provide certain working conditions } \\
\text { etc.). } \\
\text { Ecological factors (air temperature, time of day, } \\
\text { meteorological conditions, etc.). } \\
\text { Economic factors (accounting, analysis and } \\
\text { management of costs, rates for electric energy } \\
\text { and power). }\end{array}$ \\
\hline
\end{tabular}




\begin{tabular}{|c|c|}
\hline $\begin{array}{l}\text { Strategic } \\
\text { components }\end{array}$ & Detalisation of strategic components \\
\hline $\begin{array}{l}\text { ways of } \\
\text { energy } \\
\text { preservation } \\
\text { and } \\
\text { incresing } \\
\text { company's } \\
\text { energy } \\
\text { efficiency }\end{array}$ & $\begin{array}{c}\text { Realization of constant energy economy. } \\
\text { Cuts of energy losses in company's system of } \\
\text { energy supply. } \\
\text { Implementation of less energy demanding } \\
\text { technologies and equipment. } \\
\text { Electric energy efficiency increase during } \\
\text { production process. } \\
\text { Efficiency increase of company's system of } \\
\text { energy transmission and distribution. }\end{array}$ \\
\hline $\begin{array}{l}\text { stages of } \\
\text { energy } \\
\text { management } \\
\text { and } \\
\text { increasing } \\
\text { company's } \\
\text { energy } \\
\text { efficiency }\end{array}$ & $\begin{array}{l}\text { Energy consumption examination (energy audit). } \\
\text { Development of a set of activities aimed at } \\
\text { increasing energy efficiency, it includes } \\
\text { - Organizational activities aimed at increasing } \\
\text { energy preservation and energy efficiency of } \\
\text { production process. } \\
\text { - Technical activities aimed at increasing energy } \\
\text { efficiency of main and auxiliary production lines. } \\
\text { - Development of computer-controlled system for } \\
\text { accounting controlling electric energy } \\
\text { consumption. } \\
\text { - Activities aimed at increasing power supply } \\
\text { system efficiency. } \\
\text { Technical and economic grounding for suggested } \\
\text { activities. } \\
\text { - Implementation of previously developed set of } \\
\text { activities. } \\
\text { - Monitoring of results of implementation of } \\
\text { activities aimed at energy preservation, for futher } \\
\text { analysis. }\end{array}$ \\
\hline $\begin{array}{l}\text { stages of } \\
\text { company's } \\
\text { energy costs } \\
\text { management }\end{array}$ & $\begin{array}{l}\text { Operative management of energy consumption } \\
\text { can be achieved by immediate reaction on } \\
\text { changes in internal and external environment of a } \\
\text { company. It can be also achieved by constant } \\
\text { interaction with production systems of a company } \\
\text { and decrease in amount of discrepancies between } \\
\text { planned and fact energy consumption, which } \\
\text { leads to minimized fees that company pays for } \\
\text { instability on a balancing market. } \\
\text { Strategic management of energy consumption can } \\
\text { be achieved by development and implementation } \\
\text { of organizational and technical activities aimed at } \\
\text { lowering energy costs, which, in its turn, can be } \\
\text { achieved by optimizing energy consumption } \\
\text { patterns (decreasing energy consumption during } \\
\text { peak-load hours and increasing it gradually } \\
\text { during the last part of day). }\end{array}$ \\
\hline $\begin{array}{l}\text { ways of } \\
\text { reducing } \\
\text { costs of } \\
\text { acquired } \\
\text { electric } \\
\text { energy and } \\
\text { power }\end{array}$ & $\begin{array}{l}\text { Cooperation with a reliable power supplier, } \\
\text { offering the most economically beneficial terms. } \\
\text { Choosing the most economically suitable rate for } \\
\text { electric energy and power according to } \\
\text { company's energy consumption pattern, or } \\
\text { optimization of present energy consumption } \\
\text { pattern in order to correlate it with the most } \\
\text { economically beneficial rate for electric energy. } \\
\text { Adaptation of company's structure of power grid } \\
\text { equipment and improvement of electric energy } \\
\text { and power commercial accounting system. } \\
\text { Changing company's energy consumption } \\
\text { pattern. }\end{array}$ \\
\hline $\begin{array}{l}\text { factors that } \\
\text { affect } \\
\text { company's } \\
\text { energy costs } \\
\text { management }\end{array}$ & $\begin{array}{c}\text { External factors } \\
\text { - Activity of federal and local governments (FRS, } \\
\text { FAS, local executive body of power operating in } \\
\text { the field rates regulation). } \\
\text { - Activity of guaranteeing suppliers and retail } \\
\text { energy sales companies. }\end{array}$ \\
\hline
\end{tabular}

\begin{tabular}{|c|c|}
\hline $\begin{array}{l}\text { Strategic } \\
\text { components }\end{array}$ & Detalisation of strategic components \\
\hline & $\begin{array}{l}\text { - Activity of commercial infrastructure } \\
\text { companies of electric energy and power } \\
\text { wholesale market ("TSA", JSC). } \\
\text { - Activity of companies of technological } \\
\text { infrastructure of the market ("SO UPS", JSC). } \\
\text { - Generating companies and power suppliers } \\
\text { activity. } \\
\text { • Other electric energy consumers. } \\
\text { Internal factors } \\
\text { - Technological pattern and schedule of } \\
\text { production. } \\
\text { - Technical specifications of electric equipment } \\
\text { used by company } \\
\text { - Structure and specifications of external power } \\
\text { supply system. } \\
\text { - Structure and specifications of electric energy } \\
\text { and power commercial accounting system. }\end{array}$ \\
\hline
\end{tabular}

It should be noted that the strategy for energy preservation and efficiency is aimed at reducing the amounts of electric energy consumption. Strategy for energy costs management is aimed at reducing the costs of acquired electric energy and power. Both strategies are interrelated and affect each other. While carrying out one strategy, one should take into account the aims of the other one.

The division of strategy of rational energy consumption into parts makes it possible to

- Show the factors of external and internal environment, that affect the formation of energy costs, for their detailed analysis and increasing the quality of evaluation of their impact.

- Simplify the procedure of formation of target values for the evaluation of the efficiency of rational energy consumption management, and also simplify the procedure of planning of these target values.

- Elaborate complex sets of organizational and technical activities aimed at general strategic goals.

- Simplify the procedure of planning and the mechanism of realization for activities prepared for implementation.

- Increase the quality of evaluation (monitoring) of implemented activities.

- Elaborate the necessity for correcting actions, that can improve other activities aimed at rational energy consumption in a company, also define the directions of these actions.

- Organize company's energy management in a proper way.

- Define the directions of strategic and dynamic energy management.

The realization of strategy of rational energy consumption is a powerful mechanism that helps - Achieve the most suitable energy consumption pattern according to present conditions of electric energy and power market.

- Increase financial and economic stability, efficiency, competitive ability and investment attractiveness of an industrial company. 


\section{Conclusions}

On the basis of the analysis of Russian energy sector reformation, it is considered here as ineffective. It is stated that the prices for electric energy have grown significantly, and due to this appears the problem of increasing energy costs for industrial companies. In order to solve the problem we offer and ground the necessity of implementation of strategy of rational energy consumption.

The analysis of peculiarities of electric energy and power as products and the structure of electric energy and power market has let us state and ground the necessity of regulation of energy consumption patterns of industrial companies taking into account both shortterm and long-term condition of electric energy and power market.

The notion of "strategy of rational energy consumption" is specified, its goals, subjects, directions and mechanisms are defined. The characteristic feature of this strategy is its division into two substrategies: substrategy for energy preservation and efficiency and substrategy for energy costs management.

The work was supported by Act 211 Government of the Russian Federation, contract № 02.A03.21.0011.

\section{References}

1. Russian Federation Government Resolution, On the reform of the Russian power (2001)

2. Federal Law, On Electric Power Industry (2003)

3. Russian Federation Government Resolution, On approval of the wholesale market of electric power and capacity of the Rules and on Amendments to Certain Acts of the Russian Federation on the issues of functioning of the wholesale electricity market and power (2010)

4. Russian Federation Government Resolution, On the functioning of retail electricity markets, the full and (or) partial restriction mode electric power consumption (2012)

5. The Federal Law, On energy saving and energy efficiency improvements and on Amendments to Certain Legislative Acts of the Russian Federation (2009)
6. GOST R ISO 50001-2012, Energy management systems. Requirements with guidance for use

7. Russian Government Resolution, On approval of rules of non-discriminatory access to electricity transmission and delivery of these services (2004)

8. Regulation of the Russian Government, On the Energy Strategy of Russia for time period untill 2030 (2009).

9. The Russian Federation Government Resolution, On the mechanism of promoting the use of renewable energy in the wholesale market of electric energy and power (2013)

10. Analytical report: analysis of electricity reform and proposals to increase its efficiency, (Moscow, Russia, 2013)

11. E.Z. Dambaeva, Bulletin of Irkutsk State Economic Academy, 2, 78-81 (2010)

12. R.B. Naumkin, Bulletin of the Kuzbass State University, 6, 121-127 (2014)

13. D.V. Balandin, Vestnik St. Petersburg State University, 8, 167-188 (2005)

14. I.A. Gerasimov, Russian journal of scientific publications, 1, 58-61 (2012).

15. M.Y. Mishina, O.N. Polyakova, Herald Bryansk State University, 3, 62-64 (2012)

16. I.A. Baev, I.A. Soloviev, A.P. Dzyuba, Economics, management and investment, 2, 23-43 (2014)

17. A.I. Dovgyallo, D.A. Dovgyallo, S.O. Nekrasov, A.I. Dovgyallo, Energy management: electronic edition (Samara, Russia, 2011)

18. G.F. Kayachev, M.P. Govorushkin, Bulletin of the Krasnoyarsk State Agrarian University, 11, 20-24 (2014)

19. V.S. Salnikov, A.A. Bryksina, Izvestiya of the Tula State University. Technical science, 12, 149-155 (2013)

20. I.V. Burenina, D.A. Gamilova, S.V. Alexeyeva, Economy and Management. Scientific and practical journal, 5, 13-19 (2015)

21. D.C. Eltyshev, N.I. Khoroshev, 11, 1472-1475 (2014)

22. V.V. Odinochenkov, I.V. Gavreeva, M.Y. Mishina, Herald Bryansk State University, 3, 98-105 (2013) 